\title{
Cytotoxic effect and tissue penetration of phenol for adjuvant treatment of giant cell tumours
}

\author{
FALK MITTAG $^{1}$, CARMEN LEICHTLE $^{1}$, INA KIECKBUSCH ${ }^{1}$, HARTWIG WOLBURG $^{2}$, \\ MAXIMILIAN RUDERT ${ }^{3}$, TORSTEN KLUBA ${ }^{1}$ and ULF LEICHTLE ${ }^{1}$ \\ ${ }^{1}$ Department of Orthopaedic Surgery; ${ }^{2}$ Institute of Pathology and Neuropathology, Department of General Pathology, \\ University Hospital Tuebingen, Tuebingen $72076 ;{ }^{3}$ Department of Orthopaedic Surgery, \\ University Hospital Wuerzburg, Wuerzburg 97074, Germany
}

Received September 19, 2012; Accepted December 10, 2012

DOI: $10.3892 / 01.2013 .1244$

\begin{abstract}
Local adjuvant treatment of giant cell tumours (GCTs) of the bone with phenol has led to a significant reduction in recurrence rates. In the current study, the optimal phenol concentration and duration of intralesional exposure were evaluated. Specimens of GCTs were exposed to various concentrations of phenol solution $(6,60$ and $80 \%)$ for either 1 or 3 min. Following embedding in glutaraldehyde, the tumour cell layers were examined by transmission electron microscopy. Destroyed cell organelles indicated the penetration depth as a sign of denaturation. Incubation of GCT specimens with $6 \%$ phenol solution for 3 min resulted in the most tissue damage and the deepest tissue penetration of $\sim 200 \mu \mathrm{m}$. Incubation with 60 and $80 \%$ phenol solution reached a penetration depth of only $\sim 100 \mu \mathrm{m}$. Phenol instillation may be used for the treatment of small scattered cellular debris following intralesional curettage; however, it is not suitable for treatment of remaining solid tumour tissue of GCT. The use of high phenol concentrations has no benefit and increases the risk of local or systemic intoxication.
\end{abstract}

\section{Introduction}

Giant cell tumours (GCTs) account for $\sim 8 \%$ of all bone tumours $(1,2)$, commonly arising from the meta-epiphyseal region of the knee (condyles and tibial plateau), proximal humerus and distal radius $(3,4)$. Wide resection of these tumours lowers the local recurrence rate but often results in a loss of function due to extensive joint resection $(2,3)$. Therefore, extended intralesional curettage has become the recommended treatment $(5,6)$. Combined with various

Correspondence to: Dr Falk Mittag, Department of Orthopaedic Surgery, University Hospital Tuebingen, 3 Hoppe-Seyler Street, Tuebingen 72076, Germany

E-mail: falk.mittag@med.uni-tuebingen.de

Key words: phenol, tissue penetration, giant cell tumour, GCT, cytotoxic, denaturation adjuvant therapies, including phenolisation, ethanolisation, rinsing with $\mathrm{H}_{2} \mathrm{O}_{2}$, heat (electric cauterisation or cementation) cryosurgery, burring and argon beam coagulation, recurrence rates vary from $5-50 \%$ (7-12). Among the additional adjuvant therapies, phenolisation (chemical cauterisation) and cementation (thermic cauterisation and stabilisation of the bone defect) are common treatments $(8,11,13-15)$. After curettage of the tumour a phenol solution is instilled and should cover the whole cavity. Phenol is highly toxic and supposed to eliminate the majority of the remaining tumour cells by denaturation (16). In this context, little is known concerning the necessary concentration, the duration of exposure and the depth of tissue penetration of the phenol solution. Commonly used phenol concentrations for the treatment of GCT are either low $(5-6 \%)$ or very high $(60-80 \%)(8,14,15)$. Therefore, we exposed GCT specimens to various concentrations of phenol. The time-dependent depth of tissue penetration and denaturation of cells were evaluated using transmission electron microscopy.

\section{Materials and methods}

Samples. Histologically determined GCTs of 3 patients ( 2 proximal tibia and 1 metatarsal bone) were surgically removed at the Department of Orthopaedic Surgery, Tuebingen, Germany. Additionally, 6\% phenol instillation and cementation were performed. Viable solid tumour tissue specimens $(\sim 0.5 \mathrm{~cm}$ in diameter) of the removed GCTs were obtained and tested in vitro. All patients provided informed consent to partake in the study. The study was approved by the local ethics committee (Nr. 605/2011BO2).

Preparation of specimens. Phenol solution $(6,60$ or $80 \%)$ was added to the surface of the tumour specimens for either 1 or $3 \mathrm{~min}$ in vitro. Following washing with $0.9 \% \mathrm{NaCl}$ solution, specimens were immediately embedded in paraffin, sliced and stained. In addition, following phenolisation, each specimen was examined by transmission electron microscopy. Briefly, tissues were fixed with 2.5\% glutaraldehyde (Paesel and Lorei; Frankfurt, Germany) buffered in $0.1 \mathrm{~mol} / \mathrm{l} \mathrm{caco-}$ dylate buffer ( $\mathrm{pH}$ 7.4). Thereafter, the tissues were postfixed in the same fixative as used previously for an additional $4 \mathrm{~h}$, 


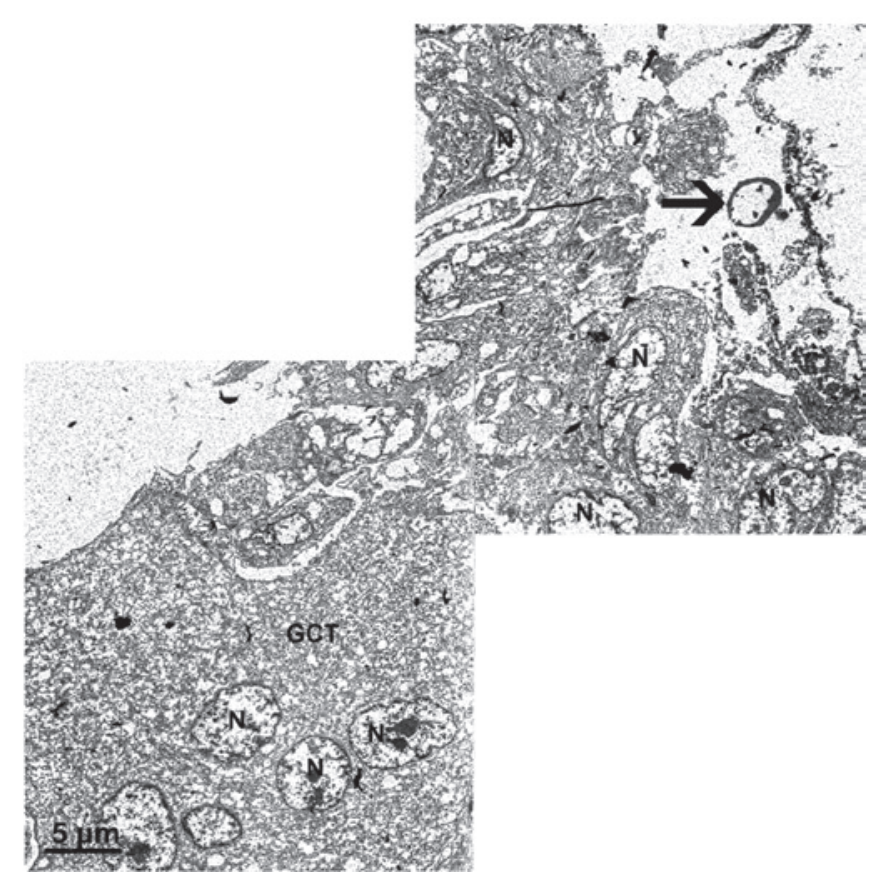

Figure 1. Electron microscopical analysis of the treatment of a giant cell tumour (GCT) with $6 \%$ phenol for 1 min, directly at the surface of the probe. The arrow indicates a cell that was completely coagulated; however, this zone of destruction remains rather small. Only $10-15 \mu \mathrm{m}$ from the phenol diffusion front, the cellular structure is observed to be normal. A cell of the GCT with several nuclei $(\mathrm{N})$ is shown.

then post-fixed in $1 \% \mathrm{OsO}_{4}$ in $0.1 \mathrm{~mol} / 1$ cacodylate buffer and dehydrated in an ethanol series (50, 70, 96 and 100\%). The $70 \%$ ethanol solution was saturated with uranyl acetate for contrast enhancement. Dehydration was completed in propylene oxide. The specimens were embedded in Araldite (Serva; Heidelberg, Germany). Semi- and ultra-thin sections were produced on an FCR Reichert Ultracut ultramicrotome (Leica, Bensheim, Germany). The semi-thin sections were stained with toluidine blue for inspection, while the ultra-thin sections were mounted on pioloform-coated copper grids, contrasted with lead citrate, and analysed and documented with an EM10A electron microscope (Carl Zeiss; Oberkochen, Germany). The penetration depth of phenol was observed to be dependent on the destruction of cell organelles in the deeper cell layers.

\section{Results}

Incubation with $6 \%$ phenol solution for $1 \mathrm{~min}$ resulted in a damage to only the uppermost cell layers (10-20 $\mu \mathrm{m}$; Figs. 1 and 2). Damage was represented as a complete coagulation of the cytoplasm and in particular the nucleoplasm. No complete loss of any of the cell substructures was observed. The outlines of the organelles were simply converted to black. After $3 \mathrm{~min}$, the penetration depth increased to $\sim 200 \mu \mathrm{m}$. Incubation with the 60 and $80 \%$ phenol solution for $1 \mathrm{~min}$ resulted in the destruction of 10 cell layers and a penetration depth of $\sim 100 \mu \mathrm{m}$. After 3 min of 60 and $80 \%$ phenol exposure, neither additional tissue damage or an increase in the penetration depth were observed (Fig. 3 and Table I).

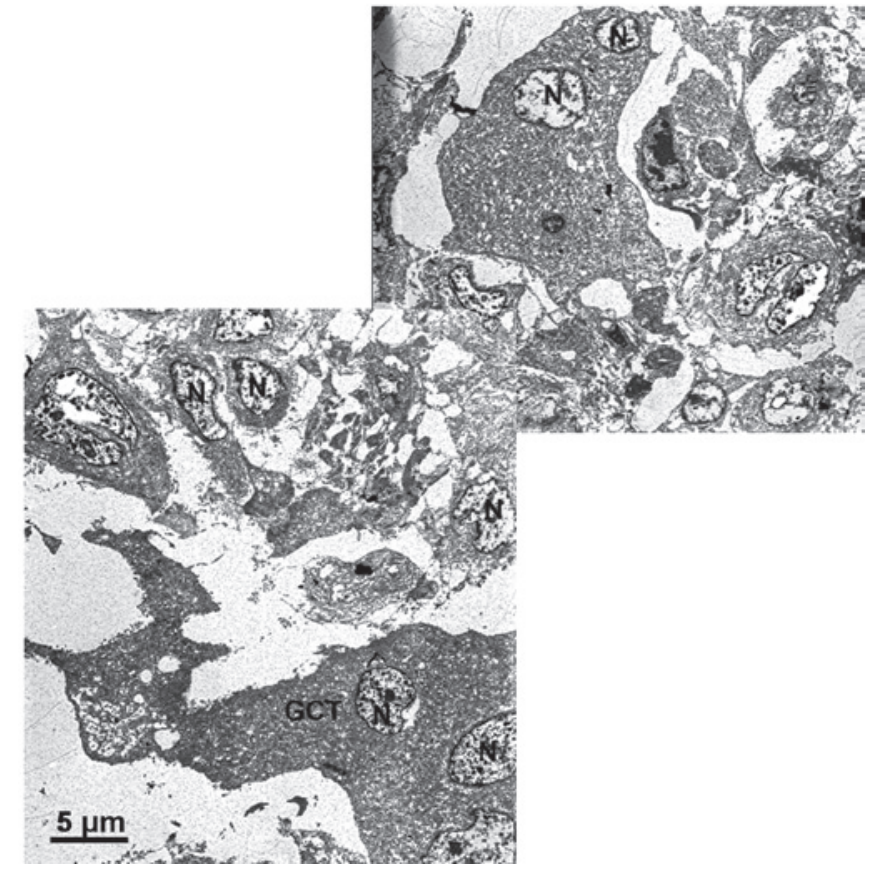

Figure 2. Electron microscopical analysis of the treatment of a giant cell tumour (GCT) with $6 \%$ phenol for $1 \mathrm{~min}, \sim 10 \mu \mathrm{m}$ along from the zone shown in Fig. 1. As already evident in the left panel of Fig. 1, the cellular structure is relatively well maintained.

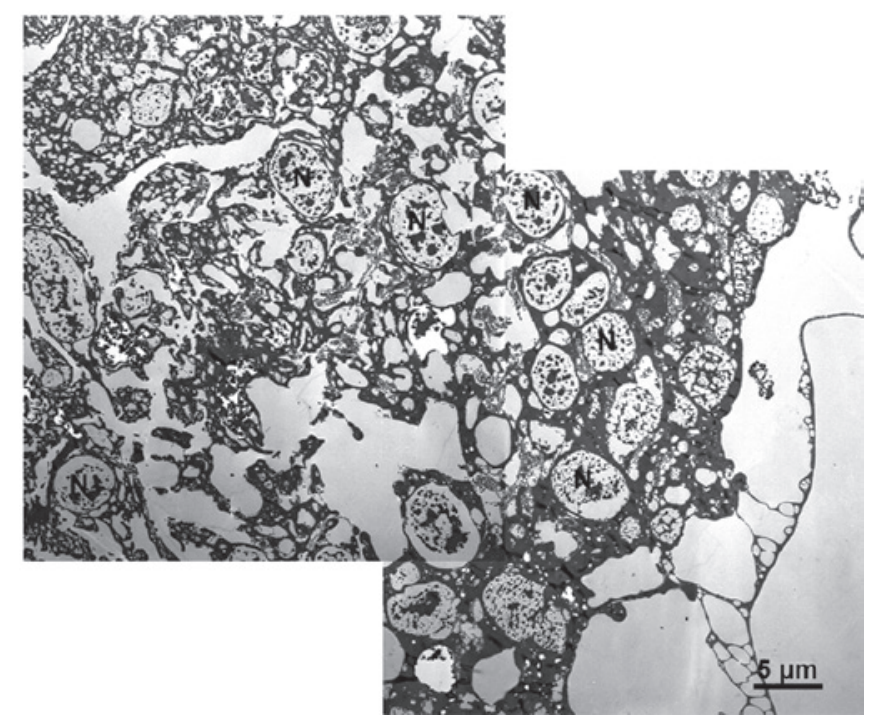

Figure 3. Electron microscopical analysis of the treatment of a giant cell tumour (GCT) with $80 \%$ phenol for $3 \mathrm{~min}$, directly at the surface of the probe. In contrast to the lower phenol concentrations and lower treatment time, all cells are completely coagulated. The cells are visualised only as scaffolds of coagulated proteins, and no longer as complex structures of cyto- and nucleoplasms enclosed by cell membranes or nuclear envelopes, respectively. Therefore, this type of cell death cannot be categorised as necrosis or apoptosis, as these processes both precede reactive or even active mechanisms as a response to toxic agents of different types. In this case, an immediate passive coagulation of cells treated with phenol and not characterised by a specific biological reactivity is observed.

\section{Discussion}

The greatest penetration depth and tissue destruction in GCT were observed when $6 \%$ phenol solution and a contact time 
Table I. Penetration depth of phenol in GCT specimens incubated with different concentrations of phenol soution.

\begin{tabular}{|c|c|c|c|c|}
\hline \multirow[b]{2}{*}{ Phenol concentration $(\%)$} & \multirow[b]{2}{*}{ Exposure time (min) } & \multicolumn{3}{|c|}{ Penetration depth $(\mu \mathrm{m})$} \\
\hline & & Specimen 1 & Specimen 2 & Specimen 3 \\
\hline 6 & 1 & 15 & 10 & 25 \\
\hline 6 & 3 & $180-200$ & No data & 200 \\
\hline 60 & 1 & 160 & 80 & 100 \\
\hline 60 & 3 & 80 & 100 & No data \\
\hline 80 & 1 & 80 & $80-90$ & 60 \\
\hline 80 & 3 & $80-100$ & 100 & 100 \\
\hline
\end{tabular}

GCT, giant cell tumour; incubation with $6 \%$ phenol solution for 3 min resulted in the deepest tissue penetration.

of $\geq 3$ min were employed. This type of destruction cannot be described as cell death in the sense of necrosis or apoptosis, as such types of cellular destruction imply a reaction (necrosis) or an active execution (apoptosis) as a consequence of toxic treatment. Higher concentrations of phenol led to extreme destruction of the uppermost cell layers, but not to a deeper infiltration of the tissue. Superficial denaturised tissues were considered to act as a barrier preventing further penetration of phenol.

Due to the complex investigation of each single cell layer with transmission electron microscopy and the achievement of consistent results in all three tumours, we did not extend the study. Nevertheless, it is possible that a deeper tissue penetration depth may be achieved by $6 \%$ (or a slightly higher concentrated) phenol solution with an incubation time $>3 \mathrm{~min}$. This requires further investigation.

The penetration depth of various concentrations of phenol in GCT has not yet been investigated. According to the literature, phenol concentrations used in the treatment of GCTs vary from $5-75 \%(8,14,15)$. The incubation time is often not mentioned. Quint et al investigated the cytotoxic effect of different phenol concentrations on single-layer sarcoma cell lines and recommend the use of a phenol concentration of $5 \%$ (17). Evaluation of the penetration depth was not possible with this setting. Lack et al investigated the denaturising effect of a $75 \%$ phenol solution on normal tissue, tumours and chondromatous tissue, using light microscopy (18). The penetration depth in soft tissue varied from 40-500 $\mu \mathrm{m}$. In chondromatous tissue, no cytotoxic effect was evaluated. This suggests that phenol has no toxic effect on bone.

High concentrations of phenol are capable of causing local chemical burs; contact of the healthy surrounding tissue with the solution ought to be avoided. Phenol is locally absorbed and excreted in the urine. In this regard, Quint et al described a low risk for humans depending on the quantity of $5 \%$ phenol solution used (16).

The results of the present study suggest that an instillation of $6 \%$ phenol solution for $\geq 3 \mathrm{~min}$ is the most effective method for denaturising as many of the remaining tumour cells as possible. High phenol concentrations did not demonstrate a benefit, and they increased the risk of bone necrosis and systemic intoxication. The determined optimal phenol concentration and incubation time for GCT are not transferable to the treatment of other tumours.
Phenol instillation ( $6 \%$ for $\geq 3$ min) may be used for the denaturation of small, scattered, cellular debris following intralesional curettage of GCT; however, due to the relatively low tissue penetration of $200 \mu \mathrm{m}$, it is not suitable for treatment of the remaining solid tumour tissue. Adequate surgical removal of the tumour remains to be the most important predictive factor in preventing recurrence of GCT of the bone.

\section{Acknowledgements}

The authors would like to thank Professor Aicher and Mrs. Kienzle, Center for Regenerative Biology and Medicine (ZRM, Eberhard-Karls-University Tuebingen), for their assistance and technical support in performing GCT fixation and staining.

\section{References}

1. Schajowicz F (ed): Tumors and tumorlike lesions of bone pathology, radiology and treatment. 2nd edition. Springer-Verlag, Berlin, Heidelberg, New York, pp257-299, 1994.

2. Szendröi M: Giant-cell tumour of bone. J Bone Joint Surg Br 86: 5-12, 2004.

3. Campanacci M, Baldini N, Boriani S and Sudanese A: Giant-cell tumor of bone. J Bone Joint Surg Am 69: 106-114, 1987.

4. Lee MJ, Sallomi DF, Munk PL, Janzen DL, Connell DG, O'Conell JX, Logan PM and Masri BA: Pictorial review: giant cell tumours of bone. Clin Radiol 53: 481-489, 1998.

5. Lackmann RD, Hosalkar HS, Ogilvie CM, Torbert JT, Fox EJ: Intralesional curettage for grades II and III giant cell tumors of bone. Clin Orthop Relat Res 438: 123-127, 2005.

6. Turcotte RE, Wunder JS, Isler MH, Bell RS, Schachar N, Masri BA, Moreau G and Davis AM: Canadian Sarcoma Group: Giant cell tumor of long bone: a Canadian Sarcoma Group study. Clin Orthop Relat Res 397: 248-258, 2002.

7. Balke M, Schremper L, Gebert C, Ahrens H, Streitburger A, Koehler G, Hardes J and Gosheger G: Giant cell tumor of bone: treatment and outcome of 214 cases. J Cancer Res Clin Oncol 134: 969-978, 2008.

8. Dürr HR, Maier M, Jansson V, Baur A and Refior HJ: Phenol as an adjuvant for local control in the treatment of giant cell tumour of the bone. Eur J Surg Oncol 25: 610-618, 1999.

9. Lin WH, Lan TY, Chen CY, Wu K and Yang RS: Similar Local Control between Phenol- and Ethanol-treated Giant Cell Tumors of Bone. Clin Orthop Relat Res 469: 3200-3208, 2011.

10. Malawer MM, Bickels J, Meller I, Buch RG, Henshaw R and Kollender Y: Cryosurgery in the treatment of giant cell tumor: a long-term followup study. Clin Orthop Relat Res 359: 176-188, 1999. 
11. Remedios D, Saifuddin A and Pringle J: Radiological and clinical recurrence of giant-cell tumour of bone after use of cement J Bone Joint Surg Br 79: 26-30, 1997.

12. Willert HG: Clinical results of the temporary acrylic bone cement plug in the treatment of bone tumors: a multicentric study. In: Limbsparing Surgery in Musculoskeletal Oncology. Enneking WF (ed). Churchill Livingstone, New York, pp445-458, 1987.

13. O'Donell RJ, Springfield DS, Motwani HK, Ready JE, Gebhardt MC and Mankin HJ: Recurrence of giant-cell tumors of the long bones after curettage and packing with cement. J Bone Joint Surg Am 76: 1827-1833, 1994.

14. Schiller C, Ritschl P, Windhager R, Kropej D and Kotz R: The incidence of recurrence in phenol treated and non-phenol treated bone cavities following intralesional resection of non-malignant bone tumors. Z Orthop Ihre Grenzgeb 127: 398-401, 1989 (In German).
15. Szendröi M: Adjuvant therapy (phenol, bone cements) in giant cell tumors. Z Orthop Ihre Grenzgeb 130: 95-98, 1992 (In German).

16. Quint U, Müller RT and Müller G: Characteristics of phenol. Arch Orthop Trauma Surg 117: 43-46, 1998.

17. Quint U, Vanhöfer U, Harstrick A and Müller RT: Cytotoxicity of penol to musculoskeletal tumours. J Bone Joint Surg Br 78: 984-985, 1996.

18. Lack W, Lang S and Brand G: Necrotising effect of phenol on normal tissues and on tumors. Acta Orthop Scand 65: 351-354, 1994. 